of organic mud, which in turn rests on an alluvial soil consisting very largely of calcium carbonate.

The Plaine du Cul-de-Sac is rather arid, and the existence of the swamp depends largely on the inflow of a number of springs, appearing from under the edge of a bed of Pleistocene coral limestone, on or near its northern shore. Water may also be added by the River Blanche from the south side of the valley.

The swamp vegetation is fairly varied, but rushes (reaching a height of $3-4 \mathrm{~m}$. above the water-level) and sedges greatly predominate. Most of the bottom is densely carpeted with Chara and Utricularia. There is practically no growth of surface-covering plants.

Data from Woodring, Brown and Burbank ${ }^{3}$, show that the temperature is remarkably equable. The average mean for the warmest three months (JuneAugust) is $28.5^{\circ} \mathrm{C}$. at Port-au-Prince. For the coldest three (December-February) it is $25 \cdot 7^{\circ}$, or only $2 \cdot 8^{\circ}$ cooler. The yearly mean is about $27^{\circ}$ (figures for seven and a half years). All these temperatures are greater than those of the Paraguayan Chaco, and considerably greater than those of the African swamp regions.

The rainfall, which is very variable at Thomazeau, over 13 years averaged: April-September, $569 \cdot 5$ $\mathrm{mm}$. ; October-March, $292.9 \mathrm{~mm}$. ; year, $862 \cdot 4 \mathrm{~mm}$. The level of the swamp does not vary markedly with the change of season, but rises and falls to a great degree over periods of several years, sometimes becoming nearly dry. At the time of my visit it was close to its maximum level. Observations were first made on a small open space between clumps of rushes. Later in the day a deeper and better-shaded pool was investigated :

Station 1, Feb. 15, 1933, 9.30 a.m. Direct sunlight. Depth of water $35 \mathrm{~cm}$. Air temperature (shade) $31 \cdot 6^{\circ} \mathrm{C}$.

\begin{tabular}{|l|c|c|c|c|}
\hline & $\begin{array}{c}\text { mgnı. oxygen } \\
\text { per litre }\end{array}$ & Phosphorus & $p \mathrm{H}$ & Temperature \\
\hline $1 \mathrm{~cm}$. under surface & $8 \cdot 5$ & $\begin{array}{c}\text { trace } \\
\text { trace }\end{array}$ & $\begin{array}{r}7 \cdot 2 \\
7 \cdot 2\end{array}$ & $\begin{array}{r}28 \cdot 2^{\circ} \mathrm{C} . \\
28 \cdot 0^{\circ} \mathrm{C} .\end{array}$ \\
\hline
\end{tabular}

Station 2, Feb. 15, $1933,1.30$ p.m.

In shade. Depth of water $75 \mathrm{~cm}$. Air temperature (shade) $35^{\circ} \mathrm{C}$.

\begin{tabular}{|c|c|c|c|c|}
\hline & $\begin{array}{c}\text { mgm.oxygen } \\
\text { per litre }\end{array}$ & Phosphorus & $p \mathrm{H}$ & Temperature \\
\hline 1 cm. under surface & $4 \cdot 0$ & trace & $7 \cdot 2$ & $29 \cdot 25^{\circ} \mathrm{C}$. \\
$1 \mathrm{~cm}$. above bottom & $2 \cdot 5$ & trace & $7 \cdot 1$ & $28 \cdot 0^{\circ} \mathrm{C}$. \\
\hline
\end{tabular}

In the middle of the open stretches of water, in the centre of the swamp, the surface temperature at 3.30 p.m. was $34 \cdot 9^{\circ}$ and the $p H$ was $7 \cdot 4$. Fish were numerous, even along the bottom.

The plankton, both plant and animal, though comparatively poor in numbers at the time, was relatively rich in species. Diatoms, desmids, Volvocales, and filamentous green and blue-green Algæ were taken; as were Protozoa, rotifers (more than twenty species), Cladocera, copepods, ostracods, amphipods, and numerous dipteran and ephemerid larvæ.

The presence of adequate oxygen is shown both by analysis and by the varied fauna. The scarcity of phosphorus suggests that the productivity is largely limited by the inorganic food supply. My observations were made at the end of the dry season, and there has been practically no rain or surface drainage for about three months, so that the inorganic nutrient salts had probably approached their minimum.
Although this swamp is closer to the equator than the swamps of the Chaco, is much nearer sea-level than the African swamps, and is in a warmer climate than either of these localities, it is quite obvious that it is entirely unlike them in eharacter. A possible explanation is that the substrate of calcium carbonate tends to minimise the effects of the production of carbon dioxide and hydrogen sulphide associated with organic decay, and also makes for unusually clear water which permits photosynthesis even to the bottom.

Osborn Zoological Laboratory,

R. M. Bond.

Yale University, New Haven.

1 Carter and Beadle, J. Linnean Soc. Zool., 37, 205-258.

- Beadle, J. Linnean Soc. Zool., 38, 135-156.

${ }^{3}$ Woodring, Brown and Burbank, "Geology of the Republic of Haiti". Republic of Haiti, Dept. of Public Works, Port-au-Prince, 1924.

\section{Monetary Standards}

IN NATURE of July 22 there was an interesting letter by Prof. H. E. Armstrong on this subject. It might be pointed out that standards of weight or length can be agreed upon because they will not vary with the changing of world conditions, but the quality of value or desirability to mankind cannot be standardised; yet it is this quality which a money standard attempts to fix. The value of one commodity in the terms of some other, such as gold, must always vary in relation to the supply.

Gold may have a certain temporary qualification as a money standard but setting it up gives to gold a false value at once. Unless it is intended to encourage speculation, it seems illogical to call the honesty of banks into question when they adjust their paper promises to a changed 'desirability value' of gold.

Even the energy required to produce a commodity is not fixed, so that an energy standard is also unsatisfactory as a gauge of value.

If fixed, international, monetary ratios are really necessary, then surely they could only be set up on a basis of supply and demand by a form of permanent board which would correct such ratios periodically. Money would then become in fact, what it is in theory, nothing more than a convenient medium for exchanging goods or services, having, like a standard of weight, no intrinsic or marketable value of its own.

Corigliano-Calabro, W. S. Gatl.

Prov. Cosenza.

Italy.

Aug. 4.

\section{Albinism in the Common Frog}

ArbINISM in the common grass frog is a very rare phenomenon and as no mention is made of it in most works on albinism, its occurrence in four parts of England seems worth recording. The specimens I have seen recently came from Somersetshire, Wiltshire, Oxfordshire and Lancashire.

(1) In 1931 a boy at Yeovil School found about twenty albino tadpoles of the common frog (Rana temporaria) and took them to the biology master, Mr. G. Mumford, for identification. Mr. Mumford 